\title{
Articles
}

\author{
ANDREY SHISHKOV
}

\section{Discussing the Concept of Conservative Ecumenism}

DOI: https://doi.org/10.22394/2311-3448-2019-6-1-4-19

Andrey Shishkov - Ss. Cyril and Methodius Institute for Post-Graduate Studies; Synodal Biblical and Theological Commission of the Russian Orthodox Church (Moscow). andrey.v.shishkov@gmail.com

This article continues the discussion of the concept of conservative ecumenism proposed by the author in 2017 to describe conservative Christian alliances in defense of traditional values. Debates have mainly revolved around the use of the term "ecumenism" in the case of such alliances. This article proposes what the author calls "ecumenical consciousness" as the minimal criteria for being "ecumenical." It also considers the question of whether striving for Christian unity is a necessary criterion of ecumenism. Based on the work of George Lindbeck, the author shows that the normative image of ecumenism as a movement to achieve unity as a mandatory condition is incorrect, and that negotiating unity is not the only possible form of ecumenical interaction. The author also discusses the relationship between theology and ideology in connection with ecumenism.

Keywords: anti-ecumenism, Christian Right, conservatism, conservative Christian alliances, Ecumenical movement, ecumenism, interconfessional cooperation, Manhattan Declaration, Pan-Orthodox Council, postsecular conflicts, pro-life, traditional values, World Council of Churches, World Congress of Families. 
7 DDAY, the theme of conservative Christian alliances that defend traditional values is increasingly attracting the attention of researchers - sociologists, political scientists, religious scholars. But this phenomenon can be studied through a theological lens as well as through the methods of social and political sciences. It is theology or, more precisely, ecclesiology - the theological discipline of studying the Church - that allows us to consider conservative Christian alliances as a form of ecumenism.

The discussion of "conservative ecumenism" as a separate phenomenon, different from traditional forms of ecumenical interaction, began in 2017 with the publication of my article "Two Ecumenisms: Conservative Christian Alliances as a New Form of Ecumenical Cooperation" in the journal State, Religion, and Church in Russia and Worldwide. This theme was central to the international seminar "Ecumenism 2.0? Between Ecumenism and Anti-Ecumenism (Orthodox Cases)."1 Discussions continued in a number of subsequent publications, ${ }^{2}$ some of which were specially prepared for this issue of the journal. In this article, I would like to highlight this discussion and respond to criticism from colleagues.

\section{Historical forms of ecumenism}

The main debate has revolved around the correctness of using the term "ecumenism" for conservative Christian alliances in support of traditional values. A little history tour is necessary here. ${ }^{3}$ Ecumenism as a form of interaction between Christian churches and communities appeared more than a hundred years ago. The starting point of the ecumenical movement was the World Missionary Conference held in Edinburgh in 1910. At this conference, according to its chairman John Mott, Christians "realized that the biggest obstacle to the spread of Christianity is we ourselves" (Mott 2001, 13). One of the main topics discussed in Edinburgh was the missionary "struggle for

1. The seminar was held on March 21-24, 2018, in Vienna within the framework of the Postsecular Conflicts research project, with the participation of the Ss. Cyril and Methodius Institute for Post-Graduate Studies and the journal State, Religion, and Church in Russia and Worldwide.

2. See, for example, the section devoted to the discussion of the concept of conservative ecumenism in Religion und Gesellschaft in Ost und West 10 (2018).

3. For a more detailed overview of the history of the ecumenical movement, see Shishkov $2017,272-81$. 
souls" between Christians in non-Christian countries. This struggle, according to many participants, had only discredited Christianity in the face of a world that was not very friendly to it. The need for a single Christian witness in rapidly secularizing societies raised the question of Christian unity, which over time became the main goal of the ecumenical movement. Ecumenism can be called the Christian answer to secularization.

Early ecumenism was not a monolithic phenomenon; it consisted of different movements, each with its own goals. The most notable of these were two: the Faith and Order movement, which sought to clarify the theological conditions of church unity, and the Life and Work movement, which dealt with issues of unifying Christian social action. In 1948, various movements united to form the World Council of Churches (WCC), which became the central platform for ecumenical dialogue. Over time, regional analogues of the WCC emerged - the European Conference of Churches, the Middle East Council of Churches, the All Africa Conference of Churches, and so on. Church structures responsible for ecumenical activities have also appeared within the churches themselves. For example, after the Roman Catholic Church officially joined the ecumenical movement, it established the Pontifical Council for Promoting Christian Unity. The Russian Orthodox Church also had appropriate structures in place. ${ }^{4}$ At the level of official declarations, ecumenical structures stated the goal of the visible achievement of Christian unity, ${ }^{5}$ and at the level of practice focused on interaction in the field of social work, human rights activities, organization of joint prayer actions and pilgrimages, and so on. The term "ecumenism" has become firmly associated with the activities of the WCC, its affiliated ecumenical organizations and foundations, as well as church structures engaged in bi- and multilateral theological dialogues between churches. ${ }^{6}$ I have suggested calling this organiza-

4. In 1960, on the eve of the accession of the Russian Orthodox Church to the World Council of Churches, the Commission on Inter-Christian Relations was established, and in 1979 the Holy Synod Commission on Christian Unity. The Synodal Theological Commission was the successor of the latter in 1993, and one of its first tasks was to evaluate the results of the theological dialogue between the Orthodox Church and non-Chalcedonian Oriental churches.

5. FitzGerald 2004, 1. Achieving the visible unity of churches is also mentioned in the document "The Church: Toward a Common Vision," presented at the 1oth WCC General Assembly in Busan, 2013.

6. We are talking, for example, about official dialogues between the Orthodox and Roman Catholic Churches, or between the Roman Catholic Church and the World Lutheran 
tional type of ecumenism "classical" to distinguish it from the "conservative" type, which is not related to the WCC or the official church structures responsible for theological dialogues between individual denominations.

Conservative ecumenism is institutionalized in the form of movements whose activities revolve around the agenda of so-called "traditional values": the traditional family (anti-LGBT), life (against abortion, euthanasia, artificial insemination), and religious freedom (religious symbols in public space) (Shishkov 2017, 224). A striking example of a conservative and ecumenical organization is the World Congress of Families (WCF), perfectly described by Kristina Stoeckl (Stoeckl 2018). Another example of the institutionalization of conservative ecumenism is the pro-life movement (Martin 2018). Within the framework of conservative ecumenism, there are also bilateral church contacts and initiatives, such as the interaction between the Russian Orthodox Church and the Billy Graham Evangelical Association (Shishkov 2017, 286-94).

\section{"Ecumenical consciousness"}

Returning to the discussion on the correctness of classifying conservative Christian alliances as a form of ecumenical interaction, one should ask the question: what is ecumenism and what are the criteria for belonging to it? The phenomenon of ecumenism is not only (and not primarily) the creation of various structures for dialogue and interaction between churches and Christian communities. Ecumenism is also a new Christian worldview based on a turn toward openness and the mutual recognition of Christians of different faiths as Christians. In my article, I called this worldview "ecumenical consciousness" and suggested the minimum criteria that define it. There are three: (1) recognition of the community of Christians regardless of their religious affiliation; (2) rejection of proselytizing, that is, a form of missionary activity that is associated with a deliberate effort to convert Christians of one confession to another; and (3) a fundamental rejection of the theological language that defines Christians of other confessions in the negative terms of "heresy" and "schism" (Shishkov 2017, 273). I argued that conservative ecumenicists are bearers of ec-

Federation. These dialogues are not related to WCC structures and represent direct ecumenical contacts between faiths. 
umenical consciousness and share these ecumenical values (Shishkov 2017, 297).

Will Cohen calls my criteria ambiguous. ${ }^{7}$ In his view, following these criteria does not necessarily amount to ecumenism. For example, he speaks of a church publicist who "very much wants to include the non-Orthodox as 'all who follow Christ' but refuses to recognize the ecclesiastical nature of any non-Orthodox [Christian] community" (Cohen 2018, 26). Another example relates to Orthodox believers who say they are against proselytizing, but do not recognize the existence of other churches outside Orthodoxy (Cohen 2018, 26). In both cases, these Orthodox believers don't recognize other Christian communities as churches from a theological point of view, as part of the Church as a metaphysical reality.

However, even in classical ecumenism there is no requirement to recognize other churches as churches. Moreover, one of the key documents of the World Council of Churches states that "membership [in the WCC] does not imply that each church must regard the other member churches as churches in the true and full sense of the word" (World Council of Churches, 1950). This means that those Christians who recognize the community of Christians over confessional boundaries, denounce proselytism, and do not use the language of "heresy" and "schisms," but are not ready to recognize other Christian communities as churches in the ecclesiological sense of the word, can also be called ecumenists.

A necessary element of ecumenical consciousness, which I have missed, is the desire for the restoration of unity. Cohen writes, "An ecumenist is someone whose hope for the restoration of full unity ... makes working toward it an imperative." 8 He adds: "Many classical ecumenists, especially Orthodox or Catholic, generally have seen working for union with another church, out of a hope rooted in the recognition in that church's retention of at least certain key ecclesial elements in common, as the necessity." 9

Regina Elsner believes that I reduce the normative requirements of ecumenism exclusively to the goal of organizational unity (Elsner $2018,19)$. But as you can see above, in defending the idea that conservative Christian alliances are a form of ecumenism, I hold the oppo-

7. Cohen 2018. See also the article by W. Cohen in this issue.

8. See Cohen's article in this issue.

9. Ibid. 
site view. For such alliances, organizational unity is not the goal. Rather, they proceed from the fact that unity has already been achieved, as, for example, one of the most significant documents of conservative ecumenism - the Manhattan Declaration of 2009 - declares: "We are Christians who have joined together across historic lines of ecclesial differences to affirm our right and, more importantly, to embrace our obligation to speak and act in defense of these truths" ("Manhattan Declaration" 2009).

\section{Striving to restore unity as a criterion for ecumenism}

Cohen's comment on the need for ecumenism in the quest for the restoration of church unity raises the question of how to understand unity. The modern ecumenical theologian Dagmar Heller says that the term "unity" was understood by the ecumenical movement in different ways: (1) as a common cause, (2) as an intercommunion (that is, eucharistic communication while maintaining the autonomy of the churches), and (3) as an "organic union" (that is, a common organization) ("Khristianskii ekumenizm" 2017, 305). The first is also applicable to conservative Christian alliances. But the fact is that only the second and the third are perceived today as an ecumenical imperative. 10

In 1989, George Lindbeck, an American Lutheran theologian and longtime ecumenical activist, wrote an article in which he distinguished between two kinds of ecumenism: unitive and interdenominational. And, observing the realities of the 1980s, he came to the conclusion that interfaith ecumenism is growing and unifying ecumenism is declining. Lindbeck writes: "Christians from separate churches are doing more and more together across confessional boundaries, and yet there seems to be less and less interest in and progress towards actually uniting the churches" (Lindbeck 1989, 647).

This discovery, however, reveals an aberration that occurred in the ecumenical movement in the 1960s and 1970s rather than actually revealing the emergence of a new type of ecumenism. Lindbeck writes that at the dawn of the ecumenical movement, interfaith ecumenism

10. For example, the introduction to the WCC document "The Church: Towards a Common Vision" (2013) refers to the achievement of "visible unity in one faith and one Eucharistic fellowship" as a goal (1-2). It can be argued that this official document expresses a normative vision of unity in the ecumenical movement today. 
dominated the activities of the Student Christian Movement and the Young Men's Christian Association (YMCA). Lindbeck also considers the Edinburgh World Missionary Conference and the Life and Work movement, whose first conference was held in Stockholm in 1921, to be interdenominational ecumenism (Lindbeck 1989, 649). At the same time, initiatives that can be attributed to unifying ecumenism have emerged. First of all, the movement Faith and Order, the first conference of which was held in Lausanne in 1927.

Thus, there were initially two directions in the ecumenical movement: the first one was based on the idea of inter-Christian cooperation on various practical issues, and the second one was based on the achievement of Christian unity. That is, in the early stages of the ecumenical movement, there was no common understanding of ecumenism.

Lindbeck writes that the unitive type of ecumenism "was immensely reinforced by the entrance of the Roman Catholic Church into the ecumenical arena at the Second Vatican Council" (Lindbeck 1989, 649). In the 1960 s and 1970 s the understanding of ecumenism as a movement toward Christian unity became normative. Thus, as Lindbeck says, "an ecumenical movement which was at first largely interdenominational has become at least officially unitive" (Lindbeck 1989, 649-50).

One of the most recent official documents of the WCC - "The Church: Towards a Common Vision" (2013) - talks about the goal of the ecumenical movement as achieving visible unity, which is expressed in the joint ministry of the Eucharist. However, this unity is described in eschatological categories, that is, without hope of achieving it in the historically foreseeable future. The pessimism about the real achievement of visible unity recorded in the 2013 document contributes to the decline of unitive ecumenism, which Lindbeck wrote about as early as 1989. The new paradigm of the ecumenical movement of "unity as communion" created in the early 1990 s is more interdenominational than unitive (Shishkov 2017, 277-78).

Today, real ecumenical cooperation is based on the principles of practical interfaith rather than normative unifying ecumenism. Ecumenists no longer set themselves the goal of achieving Christian unity in the form of an intercommunity or a single organization. They view inter-Christian ecumenical interaction as a common cause. It can be a struggle for peace, care for the poor, resistance to discrimination, and so on. The members of conservative Christian alliances for the pro- 
tection of traditional values also consider their (ecumenical) interaction as a common cause - the difference is only in the agenda. Belarusian researcher Natalia Vasilevich calls the alliance a new model of unity in the ecumenical field (Vasilevich 2013, 17). She uses the term "value-based ecumenism" for conservative alliances.

Will Cohen's thesis about the desire to restore Christian unity as a necessary criterion of ecumenism is fully in the paradigm of unitive ecumenism and corresponds to the normative image that they set. ${ }^{11}$ If this criterion is accepted, then not only conservative Christian alliances, but also a significant part of early ecumenical initiatives, as well as modern ecumenical practice, are beyond the scope of ecumenism. Restoring unity implies a process to achieve it, while understanding unity as a common cause implies that the necessary degree of community has already been achieved. The actual unity on the basis of which a common cause is possible arises from the recognition of the Christian community.

\section{Militaristic rhetoric}

Another common argument against the recognition of conservative Christian alliances as ecumenical is the critique of their militaristic rhetoric, which some scholars consider incompatible with "genuine" ecumenism.

Regina Elsner writes that "the ethos of ecumenism is community as openness, reconciliation, dialogue, forgiveness and understanding - the exact opposite of what most conservative alliances represent" (Elsner 2018, 19). In her view, the principles of some interdenominational alliances are contrary to the ecumenical ethos described above, as they use the rhetoric of war and aim to create a Christian front in the international culture wars (Elsner 2018, 20).

Indeed, conservative ecumenism in its rhetoric turns to images of war and the distinction between friend and enemy. Its militaristic rhetoric is based on the idea of a common front that opposes "militant secularism and liberalism." Some conservative Christian alliances have called their interaction the "ecumenism of trenches" (Kushiner 2006). For example, Metropolitan Hilarion Alfeyev uses the front metaphor as follows:

11. The references to Lindbeck's article, which Cohen makes by offering his criterion: Cohen 2018, 26. 
The church should look for allies to protect traditional values. Attempting to build a common front against the onslaught of militant secularism is one of the main aspects of inter-Christian and interreligious dialogue. There are many things that Orthodox and Catholics and even, to a certain extent, Christians and Muslims can do together. Family, childbearing, the right of all people to life, including those who have not yet been born, are quite close to the positions of traditional confessions on these issues. The joint efforts of different religions here are also possible because our polemic with secular humanism is not theological in nature. It's not like we're arguing about whether or not there's a God. We argue about the place of man in the world and the future of the human community. Because the answers to moral questions depend on it, and the very survival of entire peoples depends on the answers to these questions today. (Alfeyev 2009)

It should be noted here that the "openness, reconciliation, dialogue, forgiveness and understanding" that in Elsner's words characterize the ecumenical ethos have been applied by the participants of the ecumenical movement primarily to each other, that is, within the ecumenical community. It has only been since the 1970s that the idea of inclusiveness and pluralism, as well as radical openness to the Other, has become part of the classic ecumenism of the WCC, together with the left-liberal turn. Previously, pluralism had been seen as a problem rather than a solution (Kinnemon and Koup 2001, 4).

As mentioned above, the emergence of ecumenism was a kind of response to secularization. The ecumenical movement, from its earliest stages, has seen the modern world as a space for active transformation that included not only free creativity and cooperation, but sometimes also struggle. One can find criticism of various manifestations of modernity in ecumenical texts. For example, the classic ecumenical document - the Encyclical of the Ecumenical Patriarchate of 1920 - criticizes "the spreading addiction to excess luxury under the pretext of improving the standard of living and enjoying it; the overwhelming and unconstrained promiscuity and obscenity in literature, painting, theater and music under the decent banner of nurturing good taste and encouraging fine arts; the deification of physical health and disregard for the highest ideals." From the point of view of the author of the Encyclical, "all these and similar phenomena threaten the very essence of Christian society" ("Entsiklika Vselenskogo patriarkhata" 2002, 15). 
Militaristic rhetoric exists in the speeches of ecumenical figures up to the 1960s. For example, a speech by Eugene Carson Blake, who would become secretary general of the WCC a year later, reads:

Yet it is as easy as it is for all of us to turn our backs on this open door to Christian unity and engage in our religious games that have accelerated our past prejudices - at a time when units of the church's all-around enemy army are calling on the united command of Jesus Christ to stand together against the forces of atheism, scepticism, hatred and disorder that are coming upon the church. (Blake 2002, 43)

Blake's speech contains the same militaristic images that Metropolitan Hilarion's words do. In both cases, the commonalities of Christians are opposed to the "enemy": for Blake this is the power of atheism and skepticism, and for Metropolitan Hilarion it is secular humanism. Thus, the claim that militarism contradicts the "ethos of ecumenism" does not stand up to criticism. Otherwise, a significant part of ecumenism's history preceding the left-liberal turn would have to be excluded.

However, as Dagmar Heller argues, "the term 'ecumenical' is by definition inclusive. It comes from the Greek word oikumena, which the ancient Greeks used to refer to 'the entire inhabited land' ... This has two aspects: The ecumenical movement (1) invites all Christians to work together in the mission that God gave them, which is: (2) to spread the Gospel together to the whole world" ("Khristianskii ekumenizm" 2017, 309-10). But as I wrote earlier, the concept of "Christian community" in different types of ecumenism may not coincide. For example, some conservative ecumenists may not recognize liberal Christians who approve of same-sex marriages as Christians (Shishkov 2017, 297). Conservative Christians declare the upholding of traditional morality as a true preaching of the gospel.

\section{Theology versus ideology}

Finally, one can often hear another critical argument: conservative Christian alliances are not ecclesiastical, but sociopolitical structures united by a common ideology rather than theology.

From Will Cohen's point of view, the inclusion within ecumenism of forms of interdenominational cooperation that do not seek unity, such as conservative alliances, leads to "a shift in focus and meaning 
from the theological to the sociopolitical plane." 12 He defines forms of cooperation such as ecumenism as non-theological. Cohen says that this non-theological understanding of ecumenism can only be seen in ideological polarization. Cohen refers not only to conservative Christian alliances as non-theological definitions of ecumenism, but also to forms of classical ecumenism in which the element of striving for unity is lost and that are increasingly attached to the liberal trajectory set by the WCC. 13

As we have seen above, an essential element of Cohen's ecumenical consciousness is the quest for the restoration of Christian unity, which involves overcoming the theological differences between churches and Christian communities. The simple recognition of the community of Christians, upon which, for example, the interaction of conservative alliances is based, is from his point of view practically of no ecumenical importance without work to resolve theological differences. ${ }^{14}$

Theological differences are related to church doctrine, which in turn means that theology in such cases is primarily understood as dogmatic theology. The above statement by Metropolitan Hilarion - "our polemic with secular humanism is not theological in nature" - should also be understood as reducing theology only to dogmatics. The fact is that many researchers and church leaders often confine theology to the discussions that take place within the framework of bi- and multilateral theological dialogues, which really focus on the issue of overcoming doctrinal differences that hinder unification.

Despite the opposition between theology and ideology, conservative ecumenism, according to Cohen, "can also be a genuinely theological outgrowth of faith." 15

Archimandrite Cyril Hovorun also takes a stand against theology and ideology. It is worth noting that he uses the term "ideological ecumenism" in relation to the phenomenon of conservative Christian alliances under discussion (Hovorun 2017). This kind of inter-Christian interaction arises on the basis of the ideology uniting its participants. Hovorun writes:

\footnotetext{
12. See Cohen's article in this issue.

13. Ibid.

14. Ibid.

15. Ibid.
} 
The divide between "liberal" and "conservative" approaches seems to be stronger than many other divides, including theological ones. Many churches experience internal divisions along this ideological line. Conservative wings in these churches feel closer to each other than to the liberal wings in their own churches. The same applies to the liberal wings. This creates a precondition for what can be called "ideological ecumenism" - a rapprochement between the churches not on a theological basis, but on an ideological one. In this ecumenism, theology is substituted by ideology. (Hovorun 2017)

Hovorun notes that ideological alliances are not only formed on the basis of conservatism. According to him, "Liberal ideology also sometimes tried to substitute for theology in the ecumenical movements." For example, the WCC "from time to time fell into the trap of ideological bias, mostly of a leftward tilt" (Hovorun 2017).

However, from Hovorun's point of view, the fact that alliances involve themselves in a political agenda does not mean that they automatically become ideological. For example, when the themes of justice and solidarity become the basis for church collaboration, such alliances are not ideological. Hovorun writes:

Unlike ideologies, which project political programs onto religion and thus reduce the theological scope of the church, causes of justice and solidarity project the principles of Christian faith onto the public domain. These causes do not reduce or constrain the nature and purpose of the church, but implement its theological vision through social action. Therefore, this sort of social activity of the church does not incur the same sort of reductions that ideologies do. (Hovorun 2017)

Hovorun does not explain why the discourse of justice and solidarity becomes theological and the discourse of traditional values becomes ideological. In one of his previous works, Hovorun wrote that "ideology in many ways imitates theology and uses the communicative tools of the Church" (Hovorun 2014, 232). But, unfortunately, his methodology of distinguishing between theology and ideology remains unclear. Hovorun writes that unlike theology, which connects the world with the divine, ideologies keep people within the limits of earthly priorities (Hovorun 2017).

However, Hovorun is clearly in a hurry to assert that conservative ecumenism does not have its own theological discourse. Indeed, the problem of doctrinal differences is of little importance for conservative 
alliances, and therefore the role of dogmatic theology in them is not particularly pronounced. But the main line of separation of churches today, from the point of view of conservative Christians, is not on dogmatic issues, but on moral issues. In this regard, moral theology, as well as Christian anthropology, which is also a theological discipline, is beginning to play a key role. For members of conservative alliances, the issues of the beginning and end of life, gender, and family are resolved in theological discourse.

\section{Conclusion}

The foregoing discussion on "conservative ecumenism" revealed several important points. First, it showed that those who criticize the definition of conservative Christian alliances as ecumenical interaction proceed from a certain understanding of ecumenism, which is at odds with historical forms of the ecumenical movement, as well as with the modern practice of interfaith cooperation. Much of early ecumenism thus falls outside of "normative ecumenism," together with much of ecumenical practice, both conservatively and liberally oriented.

Secondly, this discussion demonstrated that the topic of conservative Christian alliances is highly politicized. For some classical ecumenists, the recognition of these alliances as ecumenism is a matter of ethical or even ideological choice. They believe that a movement that uses militaristic rhetoric, promotes violence, and sows hatred for certain groups of people cannot be considered ecumenical. And if this word is used to denote them, it is necessary to use a negative epithet "ecumenism of hate" (Spadaro, 2017) or "bad ecumenism" (Stroop, 2016). At the same time, they often emphasize that conservative ecumenists do not have their own theology, but instead their own ideology. In other words, they are doing everything they can to strip these alliances of their ecclesiastical status.

And here I need to clarify my position on this issue. While not an apologist for conservative Christian alliances, I believe that denying their ecclesial status makes it impossible to adequately describe them as a phenomenon of church life. Reducing the activities of alliances in defense of traditional values to purely political or ideological factors does not allow us to understand their religious motivation and identify the specifics of their organization.

For example, the recognition of conservative alliances as a form of ecumenical interaction makes it clear that participation in them re- 
quires adherence to at least the minimum ecumenical principles, the totality of which I have called "ecumenical consciousness." Christians who deny the presence of Christians outside their church communities, are proselytizing, or consider Christians of other denominations to be heretics and dissenters, in other words, those who can be called antiecumenists, will not be members of conservative alliances, at least not without a fundamental review of their worldview. These anti-ecumenical Christians may be committed to traditional values, have similar political views, practice the same methods of fighting for their goals, but they will never unite with other similar Christians without a minimum commitment to ecumenism. This difference is not visible through sociological or political lenses, but only through an ecclesiological perspective. Accordingly, the presence of "ecumenical consciousness" (or its absence) becomes a distinctive feature by which one can distinguish adherents of different groups and determine their motivation in public space.

In conclusion, I would like to thank all the colleagues who took part in the discussion on the topic of "conservative ecumenism." This discussion, in my view, is of great methodological importance, primarily because it allows us to rethink the established meaning of ecclesiological concepts such as Christian unity, community, ecumenical cooperation and dialogue, and so forth, in order to discover similarities and differences between different forms of ecumenical interaction, and to reactualize the experience of early ecumenism, which is still poorly understood. In addition, a theological view of conservative Christian alliances can complement the social and political science methods used to study this phenomenon.

\section{References}

Alfeev, I. 2009. "Pozitivnaia programma tserkvi - eto spasenie liudei" [The positive program of the Church is the rescue of people]. Foma 6 (74) (June). Accessed November 3, 2018, https://foma.ru/arxiepiskop-ilarion-alfeev-pozitivnaya-programmaczerkvi-eto-spasenie-lyudej.html.

Blake, E.C. 2002. "Otkrytaia dver': Propoved'-dialog s Martinom Nimëllerom, 1965” [An open door: Sermon-dialogue with Martin Niemöller]. In Ekumenicheskoe dvizhenie: Antologiia kliuchevykh tekstov, 40-43. Moscow: Bibleisko-bogoslovskii institut sv. Andreia.

Cohen, W. 2018. "Politische und theologische Motivationen der (Anti-)Ökumene." Religion \& Gesellschaft in Ost und West 10: 24-27.

Elsner, R. 2018. "Wie ökumenisch sind 'konservative christliche Allianzen'?” Religion \& Gesellschaft in Ost und West 10: 18-20. 
"Entsiklika Vselenskogo patriarkhata 1920 goda" [Encyclical of the Ecumenical Patriarchate of 1920]. 2002. In Ekumenicheskoe dvizhenie: Antologiia kliuchevykh tekstov, 1316. Moscow: Bibleisko-bogoslovskii institut sv. Andreia.

FitzGerald, Thomas E. 2004. The Ecumenical Movement: An Introductory History. Westport, CT: Praeger.

Hovorun, Cyril. 2014. “Tserkov' i ideologiia: Razdeleniia i reduktsii” [Church and ideology: Divisions and reductions]. Gosudarstvo, religiia, tserkov $v$ Rossii i za rubezhom 32 (3): $225-46$.

--_. 2017. "Ecumenism: Rapprochement through Co-working to Reconciliation.” Religions 8 (5): 70 .

"Khristianskii ekumenizm segodnia: Krizis ili transformatsiia?" [Christian ecumenism today: Crisis or transformation?]. 2017. Gosudarstvo, religiia, tserkov $v$ Rossii $i$ za rubezhom 35 (1): 302-12.

Kinnemon, M., and B. Koup [Michael Kinnamon and Brian Cope]. 2001. "Obshchee vvedenie” [General introduction]. In Ekumenicheskoe dvizhenie: Antologiia kliuchevykh tekstov, 1-9. Moscow: Bibleisko-bogoslovskii institut sv. Andreia.

Kushiner, J.M. 2006. “Christians All Together: Touchstone's Twenty Years of Friendship \& Proclamation.” Touchstone: A Journal of Mere Christianity (September/October). Accessed November 3, 2018. https://www.touchstonemag.com/archives/article. php?id=19-o8-003-e.

Lindbeck, G. 1989. "Two Kinds of Ecumenism: Unitive and Interdenominational." Gregorianum 70 (4): 647-60.

"Manhattan Declaration: A Call of Christian Conscience." 2009. First Things. 20 November. Accessed December 9, 2018. https://www.firstthings.com/web-exclusives/2009/11/ manhattan-declaration-a-call-of-christian-conscience.

Martin, J. 2018. “The Ecumenism of the Pro-Life Movement.” Public Orthodoxy, February 1. Accessed November 3, 2018, https://publicorthodoxy.org/2018/o2/o1/the-ecumenism-of-the-pro-life-movement/.

Mott, J.R. 2001. “Zakliuchitel'noe slovo na Vsemirnoi missionerskoi konferentsii, Edinburg, 1910" [Final speech on the World Missionary conference, Edinburgh, 1910]. In Ekumenicheskoe dvizhenie: Antologiia kliuchevykh tekstov, 12-13. Moscow: Bibleiskobogoslovskii institut sv. apostola Andreia.

Shishkov, Andrey. 2017. "Dva ekumenizma: Konservativnye khristianskie al'iansy kak novaia forma ekumenicheskogo vzaimodeistviia" [Two ecumenisms: Conservative Christian alliances as a new form of ecumenical cooperation]. Gosudarstvo, religiia, tserkov'v Rossii i za rubezhom 35 (1): 268-99.

Spadaro, Antonio. 2017 "Evangelical Fundamentalism and Catholic Integralism: A Surprising Ecumenism.” La Civiltà Cattolica, July 13. Accessed May 31, 2019, https://www. laciviltacattolica.it/articolo/evangelical-fundamentalism-and-catholic-integralismin-the-usa-a-surprising-ecumenism/.

Stoeckl, Kristina. 2018. “Aktivisti vne konfessional'nykh granits: 'Konservativnyi ekumenizm' Vsemirnogog kongressa semei” [Activists beyond confessional borders: The "conservative ecumenism" of the World Congress of Families]. Gosudarstvo, religiia, tserkov'v Rossii i za rubezhom 36 (4): 58-86.

Stroop, C. 2016. "Bad Ecumenism: The American Culture Wars and Russia's Hard Right Turn." Wheel 6: 21-24.

Vasilevich, N. 2013. "Orthodox Perspective of the Faith and Order Ecumenical Ecclesiological Convergence Document 'The Church - Towards a Common Vision"” (2012). Rheinische Friedrich-Wilhelms-Universität Bonn. 
World Council of Churches. 1950. "Toronto Statement: The Church, the Churches and the World Council Of Churches" WCC. Accessed May 31, 2019, https://www.oikoumene.org/en/resources/documents/central-committee/1950/toronto-statement.

World Council of Churches. 2013. The Church: Toward a Common Vision. N.p.: WCC Publications. 